\title{
Responsibilities of Land Deed Making Officials Who Do Not Apply the Prudential Principle in Making Authentic Deeds (Case Example: Decision of the DKI Jakarta High Court Number 412 / PDT / 2018 / PT.DKI)
}

\author{
Febyola Berlyani Sugiarto $^{1 *}$ Mella Ismelina Farma Rahayu ${ }^{1}$ \\ ${ }^{1}$ Tarumanagara University undergraduate student program, Grogol Petamburan, Jakarta Barat, Indonesia \\ "Corresponding author. Email: mellaismelina@fh.untar.ac.id
}

\begin{abstract}
Preparation of land sale and purchase deeds between Defendant I as buyer and Defendant II as the Official for Making Land Deeds (PPAT). Where in the making of the land sale and purchase deed made before the PPAT, Defendant I used a false identity of the owner of land and building rights named Ilyas Werdisastro (Alm) as the husband of the Plaintiff. Finally, the Plaintiff knew that there was the signature and identity of the plaintiff's husband which was falsified by Defendant I and / or Defendant II in the Sale and Purchase Deed. The main problem in this research is regarding the responsibility of PPAT which does not apply the precautionary principle in the deeds it makes and what the legal consequences are for authentic deeds if PPAT does not apply the precautionary principle. This research is a type of normative research with a prescriptive type of research. The results showed that PPAT can be held accountable because it is not careful and negligent in carrying out its duties. PPAT accountability can be in the form of administration such as verbal warning, written warning, temporary dismissal, honorific dismissal, and dishonorable dismissal. The legal consequences of authentic deeds made by PPAT without applying the principle of prudence, the strength of the evidence can turn into illegal deeds and can even be null and void because there is an element of forgery in the deed.
\end{abstract}

Keywords: Principles of prudence land title registrar, purchase and sale

\section{INTRODUCTION}

\subsection{Background}

Indonesia as a rule of law that exercises its governmental power based on law with the aim of ensuring welfare, order, certainty, protection and justice for the people. As a rule of law, it means that every society in it, including the government and state institutions, in exercising their rights and obligations must be in accordance with the applicable legal corridors [1]. Thus, a relationship between humans is regulated by law, both between individuals and individuals and between communities. This is so that law enforcement in Indonesia can be achieved properly and can create a balance to avoid disputes.

The more rapid development of the economy and socioculture in Indonesia, especially regarding the world of business in people's lives related to civil relations between individuals, makes them need a figure whose information is reliable, trusted, whose signature provides guarantees for all actions or events they do so that they have certainty. and legal protection can then be used as a powerful means of proof in the days to come [2].

The needs of the community are what make the Notary / PPAT develop in Indonesia because this is one of the characteristics and functions of the Notary / PPAT as a private institution that is not owned by other legal professions.[3] Thus the Notary / PPAT is given the authority to make an authentic deed. The authenticity of deeds made by a Notary / PPAT in their drafting shall still be guided by the provisions of the prevailing laws and regulations. Referring to Article 1868 of the Civil Code, a deed will have an authentic character, if it will have evidence between the parties and against a third party, then the actions or statements presented will provide evidence that cannot be eliminated.[4]

Although both of them have the authority to make and issue authentic deeds, the legal umbrella for the two officials is different. The overall notary authority can be seen in the provisions of Article 15 UUJN and certain powers are also regulated in other laws and regulations. [5] Meanwhile, the duties and authorities of PPAT can be seen in Government Regulation Number 24 of 2016 concerning the Position Regulations for Making Land Deeds set out in 
article 2 paragraph (1), one of which states that PPAT has the authority to make sale and purchase deeds related to land.[6] The Deed is a document that is deliberately made to be used as evidence in the event of an event and signed Notary Act is an official document issued by a notary based on Article 1870 of the Civil Code and Article 165 HIR (Herzien Inlandsch Reglement) and Rbg 285 (Rechtreglement voor de Buitengewesten) which has the power of absolute proof and binding. Based on the above provisions, there are two kinds of acts, namely the authentic act and the act under hand, which can be explained as follows:

1. Authentic Act is an act made by an official authorized for it by the ruler, according to the provisions that have been set, both with and without the assistance of the stakeholder, who records what is requested to be included in it by the stakeholder, the authentic act mainly contains the testimony of an official, which explains what he did and was seen before him. Whereas an authentic Act in accordance with the provisions of Article 1868 of the Civil Law Book (KUHPerdata) is "an authentic act is an act which is in the form determined by law, made by or in the presence of public officials in authority for that place where the deed was made."

2. The underwritten deed is an act that is free in form, its manufacture must not be in the presence of an authorized public official, still has the power of proof as long as it is not denied by the maker and if it must be proven, the proof must also be accompanied by witnesses and other evidence. Therefore, usually in the deed under hand should include 2 adult witnesses to strengthen the evidence. An authentic deed is an instrument of legal protection for its owner. In the case of land sale and purchase must be determined by an act made by and in the presence of the Land Act Making Office to ensure the certainty and legal order in the sale and purchase of the land. It is already known to the public that the importance of legality in the process of legal acts that will be done or have been done and then put it in a document in the form of an authentic deed. Public awareness of making an act in the presence of an authorized official indicates that the public has realized that in order to obtain protection and certainty over the object it possesses, it needs a tool of evidence in the form of an act.

The mutually needed relationship between PPAT and the community and the state if it goes according to the applicable legal corridors can create a positive relationship so that it is expected to provide order and security in the midst of society.[7] PPAT in carrying out its duties and authorities in making deeds is indeed demanded to be good and correct, which means that the deed fulfills the legal will and requests of the parties concerned because their position is in accordance with the law and the wishes of the parties concerned in the true meaning and does not exist there is on the deed he has drawn and must be careful in entering into the identity given by both parties. [8]

In carrying out his duties to make an authentic deed, a notary / PPAT is obliged to carry out the provisions in PP No. 24 of 2016. PPAT is obliged to act honestly, thoroughly, independently, not taking sides, and to protect the interests of parties involved in legal actions, in accordance with Article 16 UUJN.[9] As he said in the oath of office, namely in the notary oath of office in Article 4 paragraph (2) of the UUJN, namely "that I will carry out my position with trust, honesty, thoroughness, independence, and impartiality."[10] In addition, a notary / PPAT as a public official must be able to follow the development of the law so that in providing his services to the community, in helping to cope with and fulfilling the growing legal needs can provide a solution justified by law. In providing services, a notary must also maintain the noble ideals of the profession in accordance with the demands of the obligations of conscience. [11]

Based on the oath of office pronounced by the Notary / PPAT, this makes PPAT have an important role in determining whether an action can be stated in the form of a deed or not, so that the implementation of the precautionary principle must be carried out in the Deed making process, one of which is by introducing tappers based on their identities shown to the notary. This is because the legal consequences resulting from the making and signing of the PPAT deed will result in a transfer or granting of mortgage rights or granting power of attorney to impose mortgage rights for the community, and if PPAT is not careful in making the deed then the deed will be null and void. its cancellation is requested and if the PPAT deed is canceled, the PPAT may be sued for payment of compensation by the aggrieved parties.

Therefore, a legal issue arises regarding the validity of the sale and purchase deed made before the PPAT, whether the PPAT knows or not the truth of the deed made. This is because PPAT is often not careful in carrying out its profession. Among them is the lack of prudence, namely that notaries make it very easy for tappers in terms of identity. The party wishing to use the services of a notary must provide proof of correct identity by showing the original Identity Card (KTP) and providing a photocopy of it to the notary. However, in practice, in some cases that occur, even though the introduction is mandatory, there are many legal problems with notarial deeds due to false identities, documents, letters or statements which then cause harm to other parties. These problems usually occur because PPAT is not careful in the process of drafting and signing deeds, one of which is negligence when introducing the complainant and even not checking the validity of the identity of the applicant. This is like what happened in the case of identity forgery and signature in the making of the Sale and Purchase Deed in East Jakarta by faking the identity of another person who seemed to be the seller, as stated in the East Jakarta High Court Decision Number: 412 / Pdt / 2018 / PT DKI

Case discussed in this study was the case of making a land sale and purchase deed between Defendant I as the buyer and Defendant II as PPAT. Where in the making of the land sale and purchase deed made before the PPAT, Defendant I used a false identity of the owner of land and building rights named Ilyas Werdisastro (Alm). This was discovered by the Plaintiff as the wife and heir of Ilyas WerdisastroYatie when the Plaintiff received a letter from PT. Balai Mandiri Prasarana where the object in the form 
of SHM Number 244 which belongs to the plaintiff's husband has been auctioned, after further checking it turns out that SHM Number 244 has been changed to the name of Defendant I, based on the Sale and Purchase Deed No. 48/2011 made by Defendant II as PPAT. Finally, the plaintiff knew that there was the signature and identity of the plaintiff's husband which was falsified by Defendant I and / or Defendant II in the Sale and Purchase Deed.

\subsection{Problems}

Based on the background that the author has described, the author draws a problem, namely:

1. What is the responsibility of PPAT for not applying the precautionary principle in making authentic deeds?

2. What is the legal consequence of authentic deeds if PPAT does not apply the precautionary principle?

\subsection{Research Method}

1. Nature of Research

The nature of this research is prescriptive, which aims to examine whether or not rules apply, about what should be done. In other words, the goal is to realize regulations. This research is expected to provide clear information regarding the responsibility of notaries in making authentic deeds in which the applicant uses a false identity and signature as contained in the Decision of the DKI Jakarta High Court Number: 412 / PDT2018 / PT.DKI. [12]

\section{Type of Research}

The type of research used is normative legal research which is another name for doctrinal legal research which is also known as library research or document study because this research is conducted or aimed only at written regulations or other legal materials. In essence, research is carried out by examining library materials or secondary data consisting of primary legal materials, secondary legal materials and tertiary legal materials. [13]

\section{Type of data \\ Type of data is secondary:}

a. Primary data is data obtained directly from 1945 Constitution, Civil Code, Government Regulation Number 24 of 2016 concerning Amendments to Government Regulation Number 37 of 1998 concerning Land Deed Making Officials, Law Number 2 of 2014 concerning Amendments to Law Number 30 of 2004 concerning the Position of Notary Public, Notary Code of Ethics.Decision of the DKI Jakarta High Court Number: 412 / PDT2018 / PT.DKI. [14]

b. Secondary data is normative data, especially those sourced from legislation. Secondary data is usually obtained from literature studies and document studies, by collecting data from various reading sources in the form of applicable laws and regulations and literature or legal science literature relating to the problem under study.

c. Tertiary data: Tertiary data are materials that provide guidance and explanation for primary and secondary legal materials: legal dictionary and internet sites related to the accountability of notaries and the principles of good performance of notary duties. [15]

\section{Data Collection Techniques}

Literature review, Literature study is the study of written information about law that comes from various sources and is widely published and is needed in normative legal research. In this research, the literature study is carried out by reading, recording and quoting from legislation, contract manuscripts of agreements, literature books, and data through related internet searches. [16]

\section{Data Analysis technique}

This study uses data analysis techniques with deductive logic, deductive logic or processing of legal materials in a deductive way, namely explaining something that is general in nature and then drawing it into a more specific conclusion. [17]

\section{DISCUSSION}

\subsection{Overview of the Prudential Principle}

Purpose of the precautionary principle is to anticipate the occurrence of an undesirable condition from an act that someone has done. The precautionary principle comes from developing the principle of prudence. In the Black's Law Dictionary, prudence is defined as thoroughness, prevention, attention, and objective judgments as well as those contained in behavior or care. [18]

Adam Smith gave an explanation of the principle of prudence, that there is a relationship between prudence and maintaining personal life, namely that everyone is always careful and aware of himself, his interests in life, and not only thinking about his interests in the present, but also being careful about his life. in the future. So that, before doing any action, someone will think longer, namely paying attention to the consequences that will arise from the actions he is doing now.[19]

From the above understanding, it can be concluded that the precautionary principle is a mindset to consider everything before committing an action so as to avoid problems in the future.

\subsection{Accountability Theory Related to Land Deed Making Officials.}

Accountability is a condition of being obliged to bear everything (if there are things that can be sued, blamed and so on).[20] A person who is said to be legally responsible for a particular act is that he can be subject to a sanction in the case of the opposite act.

Furthermore, Andi Hamzah in his Legal Dictionary, quoting from the Big Indonesian Dictionary, stated that responsibility is the obligation to bear everything if anything happens, it can be prosecuted, blamed, and brought up against. In the legal dictionary, responsibility is 
an obligation for someone to carry out what has been obliged to him.[21]

Referring to general legal theory which states that everyone, including the government, must be accountable for every action, whether due to error or without error. From general legal theory, this will emerge as a form of legal responsibility in the form of criminal responsibility, civil responsibility, and administrative responsibility.

Van Hamel stated that the ability to be responsible is a state of psychic normality and maturity that brings three abilities, namely:[22]

1. Able to understand the value of the consequences of one's own actions.

2. Able to realize that his actions according to the view of society are not allowed.

3. Able to determine his will for his actions.

Regarding the issue of official accountability, according to Kranenburg and Vegting, there are two theories that underlie it: [23]

1. Theory of fautes personalles, which is a theory that states that losses to third parties are borne by officials whose actions have caused losses. Based on this theory, the burden of responsibility is directed to humans as individuals.

2. Theory fautes de service, namely the theory that damages against third parties are charged to the institution of the official concerned. According to this theory, responsibility lies with the position. In its application, the losses incurred are also adjusted to whether the mistakes committed are serious or minor mistakes, where the weight and lightness of an error has implications for the responsibility that must be borne.

In carrying out his position, a notary / PPAT has a moral responsibility towards his profession. According to Paul F. Camanisch, profession is a moral society that has shared ideals and values. Professional groups have their own powers and special responsibilities. As a profession, this group has a reference called the Professional Code of Ethics.[24] Violation of the position of a notary in the end will lead to accountability for the professional caretaker, both administratively responsible and civilian compensation, furthermore a notary can be criminally responsible if a notary violates the Criminal Code in carrying out his duties and positions.

Accountability must have a basis, namely things that give rise to legal rights for someone to sue others as well as things that give birth to other people's legal obligations to give accountability.[25]

In general, the principles of responsibility in law can be distinguished, namely:[26]

1. The principle ofliability based on fault, namely the principle which states that a new person can be held accountable legally if there is an element of wrongdoing.

2. The principle of presumption of liability, namely the principle that the defendant is always held responsible until he can prove his innocence, so the burden of proof rests on the defendant.

3. The principle of presumption of non-liability, which is the opposite of the principle of presumption of responsibility, in which the defendant is always considered to be irresponsible until proven that he is guilty.

4. The principle of absolute responsibility (strict liability), in this principle determines error not as a determining factor, but there are exceptions that allow it to be exempted from responsibility, for example asituation force majeure.

5. The principle of responsibility with limitations (limitation of liability), with the existence of this responsibility principle, business actors may not unilaterally determine clauses that are detrimental to consumers, including limiting their maximum responsibility. If there are restrictions, then it must be based on the applicable laws and regulations.

Meanwhile, according to Abdulkadir Muhammad that in theory the responsibility to act in violation of the law(tortliability) is divided into several theories:[27]

1. The responsibility due to unlawful deliberate (international tort liability), the defendant would have had to act in a way that harm the plaintiff or knowing that what the defendant did would result in a loss.

2. Liability due to illegal acts committed due to negligence (negligence tort liability), is based on the concept of error (concept of fault) relating to morally and law which is mixed.

3. Absolute responsibility due to illegal acts without questioning fault (strick liability), this is based on his actions either intentionally or unintentionally, meaning that even though he is not his fault, he must still be responsible for the losses arising from his actions.

Based on PP No. 24 of 2016 stipulates that when PPAT in carrying out its position is proven to have committed a violation, then PPAT must be responsible by being subject to sanctions or being sanctioned, in the form of civil sanctions, administrative sanctions, criminal sanctions, code of ethics for notary office or a combination of sanctions. These sanctions have been regulated in such a way. In practice, it is found that a legal action or violation committed by PPAT can actually be subject to administrative or civil sanctions or a code of ethics, but then it is withdrawn or qualifies as a criminal act committed by PPAT.[28]

Thus, the notary / PPAT as a public official must be responsible for the deed he has done, be it administrative accountability, civil liability if it is proven that the deed has violated a criminal act.

The first condition is to take action against a despicable act, namely the existence of a provision in the law that formulates the reprehensible act to impose sanctions on it. Law in a material sense means regulations made by the competent government agency, which are generally accepted and bind the population. Meanwhile, law in the 
formal sense means laws which are made based on the method specified in the law in the formal sense.[29]

The above explanation, in the end, can be concluded, that the person who is able to take responsibility is a person who is really able to control and control the will that will be done so that he himself understands the consequences that arise from what he does.

\subsection{PPAT's Responsibilities for Not Applying the Prudential Principle in Making Authentic Deed}

Responsibility is everything that must be borne for the actions that have been done. If associated with PPAT, he has responsibility for all deeds that he has drawn up. Therefore, PPAT must act with caution in making and signing deeds. [30]

In the PPAT position regulations, it is stated that in making an authentic deed, PPAT must conduct an introduction to the audience. Where in this case the PPAT must ensure that the actor is competent by law, besides that he is also authorized to take legal actions. This indicates that PPAT is required to apply the precautionary principle in identifying tappers.

There is an obligation to carry out the identification of tappers to ensure that the tappers are really those who are competent for legal actions. According to Tang Thong Kie, PPAT must know the tappers. "To know" in this case is to know. Notary / PPAT must bear that the name of the applicant written in the deed is really attached to that person and not to other people.[31]

In the case that the author adopts, there is an authentic deed, namely the sale and purchase deed in which the party falsifies the identity of the other party by pretending to present a fake figure in making the sale and purchase deed. In this case it shows that the PPAT is not careful in introducing tappers.

The precautionary principle is the application of article 16 paragraph (1) letter a of the UUJN, namely that one of the contents of which a notary in carrying out his obligations must act honestly and thoroughly in legal actions. In connection with the above case, it means that PPAT has violated Article 16 paragraph (1) letter a UUJN. So that PPAT can be held accountable even though in this case it is not entirely PPAT fault. PPAT can be held accountable because it has been negligent or due to its carelessness, it seems that what is stated in Article 1366 of the Criminal Code that "every person is responsible for losses arising not only because of his actions but because of his lack of care" [32]

Responsibility due to lack of prudence in relation to PPAT having violated Article 16 of the UUJN, administrative sanctions may be imposed, namely verbal warning, written warning, temporary dismissal, honorable dismissal, and dishonorable dismissal.[33] If PPAT is not careful, it can cause losses to other parties, then it can be subject to civil sanctions in the form of paying compensation, interest, and so on.[34]
In the verdict in the case, the judge decided that the PPAT had to be responsible on a civil basis, namely to pay compensation in the amount of 2,500,000,000 jointly and severally. This is because the PPAT is not careful in introducing the parties so that there is a falsified identity which results in losses to other parties.

This shows that implementing the precautionary principle must be carried out by PPAT in making authentic deeds, especially regarding the introduction of tappers. If the PPAT has applied the precautionary principle before making AJB together with the parties concerned, the PPAT will avoid problems in the future

\subsection{Legal Consequences on Authentic Deeds If PPAT Does Not Apply the Prudential Principle} The PPAT

Precautionary principle is not fulfilled in identifying actors, making the authentic deed contain false information. An authentic deed has perfect evidentiary power as long as it is not proven otherwise by one or both parties.[35] Perfect in this case, the judge considers that the contents of the authentic deed are true. However, the PPAT deed can be degraded to become under hand if in the deed there are articles which directly confirm if the Notary commits a violation, then the deed concerned is included as deed which has the power of making as an underhand deed.

The precautionary principle is the application of Article 16 paragraph (1) UUJN, in which in the case according to the author the PPAT has violated the provisions of the article so that the PPAT deed can be degraded into underhanded power of proof. However, it is different in the decisions contained in the case where the sale and purchase deed become null and void because of the element of forgery in it.

The authentic deed contains the agreement of the parties who carry out legal actions. The agreement must be in accordance with the valid terms of the agreement in Article 1320 of the Criminal Code, namely:[36]

1 . There is an agreement between the parties

2. Competent

3. A certain thing

4. A lawful cause.

If it is related to the case that the author adopted, there are at least 2 (two) valid conditions of the agreement that are not fulfilled in the sale and purchase deed, namely:

1. Agreement of the Parties

Based on this case it is clear that there is no agreement from the seller as the owner of the land and building, namely Ilyas Werdisastro and his wife, namely Roostiningsih, to approve the sale and purchase of land and buildings because the land owner and his wife were not aware of the sale and purchase and had never been present to the Notary / PPAT from the beginning of the making of the AJB to the signing of the AJB, where and the signatures of the seller and his wife were faked. 


\section{A Halal Cause}

By presenting a false figure, namely claiming to be (as if) the seller at the signing of the AJB who gave AJB his signature (imitation), against the violation of the legal conditions of the agreement, namely "a lawful cause" due to the the buyer) in bad faith faked the presence of the seller and wife as if to reverse the name of the Property Rights Certificate from Muhammad Ilyas Werdisastro into the name of the buyer and faked the signing of the AJB as if it was true Muhammad Ilyas Werdisastro signed it, so that the signing in the AJB is fake.

So that according to the author's analysis regarding the validity of this sale and purchase is not fulfilled or not valid. Because there are 2 (two) terms of the agreement that are not fulfilled, namely the agreement of the parties and a lawful cause. Thus, due to the non-fulfillment of these subjective and objective terms, the Sale and Purchase Deed made by the parties becomes null and void, this is due to the failure to fulfill the objective elements in the agreement for which the deed was made where this objective element is contained in the deed so that if the body of the deed does not contain an objective element, then the deed is deemed to have never existed.[37]

The emergence of a legal consequence on authentic deeds which become null and void by law, is due to the fact that PPAT does not apply the precautionary principle in making deeds. The PPAT should have been able to carry out a thorough examination of the identity of the parties, namely matching the identity of the tappers again with the tappers in front of them as a sign that PPAT is careful in identifying the tappers. So that the PPAT avoids problems regarding falsification of identity at a later date and the deed he makes is avoided from a problem.

\section{CLOSING}

\subsection{Conclusion}

Based on the results of the studies that have been carried out and based on the theories that have been put forward, the author can draw a conclusion, namely

1. In making authentic deeds that do not fulfill the precautionary principle, they can be held accountable in the form of administrative responsibility, namely being sanctioned by verbal warning, written warning, temporary dismissal, honorific dismissal, and illegal dismissal. honored. Apart from that, the civil liability is in the form of compensation. This is based on the rules of Article 1366 of the Civil Code in which every person must be responsible for losses that arise not only because of his own fault but due to a lack of caution.

2. The legal consequences of an authentic deed in which the Land Deed Maker Officer does not apply the precautionary principle, the deed contains falsification, that is, there is falsification of the identity of another party. So that the sale and purchase deed become null and void.

\subsection{Suggestion}

Based on the above conclusions, the following suggestions can be given, considering that the Notary / PPAT profession is a legal practitioner, where his signature guarantees legal certainty for the parties, in making the deed more accurate and wiser by prioritizing prudence Consider and uphold the professional code of ethics, and do not really make it easy for customers on the grounds of service. This is useful for the Notary / PPAT itself if there is a problem concerning the Notary / PPAT at a later date.

\section{REFERENCES}

[1] Theo Huijbers, Filsafat Hukum, Kanisius, (Yogyakarta: Kanisius, 1990), 145.

[2] Ghansam Anand, Karakteristik Jabatan Notaris Indonesia, (Jakarta: Kencana, 2018), 51

[3] Muhammad Adam, Asal Usul dan Sejarah Akta Notaris, (Bandung: Sinar Bandung, 1985), 31.

[4] R Subekti dan R. Tjitrosudibio. Kitab Undangundang Hukum Perdata (KUH Perdata). (Jakarta: Pradnya Paramita, 2003), Pasal 1868

[5] Indonesia, Undang-Undang Nomor 2 Tahun 2014 tentang Perubahan Undang-Undang Nomor 30 Tahun 2004 tentang Jabatan Notaris, Pasal 15

[6] Indonesia, Peraturan Pemerintah Nomor 37 Tahun 1998 tentang Peraturan Jabatan Pejabat Pembuat Akta Tanah, Pasal 1 Ayat (1), jo Peraturan Pemerintah Nomor 24 Tahun 2016 tentang Perubahan Atas Peraturan Pemerintah Nomor 37 Tahun 1998 tentang Peraturan Jabatan Pembuat Akta Tanah

[7] R. Subekti, Hukum Pembuktian, (Jakarta: Pradnya Paramita, 2001), 48

[8] A. Muhammad, Etika Profesi Hukum, (Bandung: Citra Aditya Bakti, 1997), 60

[9] Indonesia, Undang-Undang Nomor 2 Tahun 2014 tentang Perubahan Undang-Undang Nomor 30 Tahun 2004 tentang Jabatan Notaris, Pasal 16

[10] Indonesia, Undang-Undang Nomor 2 Tahun 2014 tentang Perubahan Undang-Undang Nomor 30 Tahun 2004 tentang Jabatan Notaris, Pasal 4 ayat (2).

[11] H. Ajie, Kebatalan dan Pembatalan Akta Notaris, (Bandung: PT. Refika Aditama, 2011), 9 
[12] P. M. Marzuki, Penelitian Hukum, (Jakarta: Kencana Prenada Media Group, 2011), 35

[13] J. Ibrahim, Teori dan Metodologi Penelitian Hukum Normatif, (Malang: Bayu Publishing, 2006), 28

[14] Soekanto, Pengantar Penelitian Hukum, Cetak Ketiga, (Jakarta: UI Press, 2012) hal.15

[15] S. Mertokusumo, Penemuan Hukum Sebuah Pengantar, (Yogyakarta: Liberty, 2014), 33

[16] P. M. Marzuki, Penelitian Hukum, (Jakarta: Kencana Prenada Media Group, 2011), 93

[17] P. M. Marzuki, Penelitian Hukum, (Jakarta: Kencana Prenada Media Group, 2011), 24

[18] H. C. Black, Black's Law Dictionary: Definitions of The Terms and Phrases Of American And English Jurisprudence, Ancient And Modern, West Publishing Co, St. Paul, Minn,1968, 1468.

[19] A. Smith Dalam Sonny Keraf, Pasar Bebas, Keadilan Dan Peran Pemerintah, (Yogyakarta: Kanisius, 1996), 107

[20] W.J.S Poewadarminta, Kamus Bahasa Indonesia, (Jakarta: Balai Pustaka, 1982), hal. 1014

[21] M. Luthfan Hadi Darus, Hukum Notariat dan Tanggungjawab Jabatan Notaris, (Yogyakarta: UII Press, 2017), hal. 48

[22] E. Yunara, Korupsi dan Pertanggungjawaban Pidana Korporasi, (Bandung: PT. Citra Aditya Bakti, 2010), hal.54

[23] H. R. Ridwan, Hukum Administrasi Negara, (Jakarta: Raja Grafindo Persada, 2011), hal. 336

[24] E. Sumaryono, Etika Hukum Profesi, (Yogyakarta: Kanisius, 2012), hal.

[25] T. Triwulan dan S. Febrian, Perlindungan Hukum Bagi Pasien, (Jakarta: Prestasi Pustaka, 2010), 48

[26] Shidarta, Hukum Perlindungan Konsumen, (Jakarta: PT. Grasindo, 2000), 58

[27] A. Muhammad, Hukum Perusahaan Indonesia, (Bandung: Citra Aditya Bakti, 2010), 503.

[28] H. Adjie, Kebatalan dan Pembatalan Akta Notaris, (Bandung: PT. Refika Aditama, 2011),120.
[29] M. Luthfan Hadi Darus, Hukum Notariat dan Tanggungjawab Jabatan Notaris, (Yogyakarta: UII Press, 2017), 52

[30] M. Luthfan Hadi Darus, Hukum Notariat dan Tanggungjawab Jabatan Notaris, (Yogyakarta: UII Press, 2017), 48

[31] T. T. Kie, Serba-Serbi Praktek Notaris, (Jakarta: PT Ichtiar Baru Van Hoeve, 1994), 58

[32] R Subekti dan R. Tjitrosudibio. Kitab Undangundang Hukum Perdata (KUH Perdata). (Jakarta: Pradnya Paramita, 2003), Pasal 1366

[33] Indonesia, Undang-Undang Nomor 2 Tahun 2014 tentang Perubahan Undang-Undang Nomor 30 Tahun 2004 tentang Jabatan Notaris, Pasal 16, ayat 1 huruf a

[34] R Subekti dan R. Tjitrosudibio. Kitab Undangundang Hukum Perdata (KUH Perdata). (Jakarta: Pradnya Paramita, 2003), Pasal 1365

[35] R. Subekti, Hukum Pembuktian, (Jakarta: Pradnya Paramita, 2001), 48

[36] R Subekti dan R. Tjitrosudibio. Kitab Undangundang Hukum Perdata (KUH Perdata). (Jakarta: Pradnya Paramita, 2003), Pasal 1320

[37] H. Adjie, Kebatalan dan Pembatalan Akta Notaris, (Bandung: PT. Refika Aditama, 2011), 120 